\title{
TEACHING LEADERSHIP AND ADMINISTRATION AT A FACULTY OF THEOLOGY: PRACTICAL-THEOLOGICAL REFLECTIONS ${ }^{1}$
}

\author{
Ian A Nell \\ Practical Theology and Missiology \\ Stellenbosch University
}

\begin{abstract}
The on-going processes of decline taking place in mainline churches all over the world in combination with developments in the direction of pluralism, consumerism and globalization pose many challenges to the teaching of leadership and administration at Faculties of Theology. Not only do we find much "crisis language" and even some unease with the use of leadership terminology in theological discourses, but we also see challenges to deeply-held convictions on the traditional understanding of the offices and ministry of the church. The values and underlying assumptions about these notions are contested areas in scholarly research. At the same time we see the development of alternative forms of leadership as well as the rapid growth of African Independent Churches within the African context. The article probes different aspects of leadership and administration and attempts to clarify some points of departure for the on-going conversation. Part of the argument is that the teaching of leadership and administration, in preparing students for their role in Christian faith communities, rests upon four different pedagogies. These pedagogies each contribute towards an integrated spirituality as a prerequisite for authentic leadership. In conclusion, some practical suggestions are proposed as pointers for the future for teaching this challenging field at Faculties of Theology.
\end{abstract}

We all hoped that the students who went through these institutions would be able to think theologically, apply what they had learnt to their contexts relevantly, think critically, and act prophetically - that they would exercise their ministerial functions competently and that they would be persons who were growing in their spiritual and prayer life. ${ }^{2}$

- Archbishop Emeritus Desmond Tutu

Key Words: Leadership; Administration; Theological Education; Pedagogy; Faith Formation

\footnotetext{
This article was delivered as a paper at an international conference of the MTB (Moluks Theologisch Beraad) in Houten, the Netherlands from 31 October to 2 November 2012. The theme of the conference was The role of Theological Institutions in building church leaders for the future. Partner institutions that took part were Free University of Amsterdam, Stellenbosch University, Beyers Naudé Centre for Public Theology, the International Reformed Institute, the Protestant Church in the Netherlands and the Universitas Kristen Indonesia Maluku.

2 These words of Archbishop Emeritus Desmond Tutu are a reflection on the time of his involvement with the Theological Education Fund (TEF) of the World Council of Churches during the seventies of the previous century and form part of a new publication: Naidoo, M. (ed.) 2012. Between the Real and the Ideal: Ministerial Formation in South African Churches.Pretoria: Unisa Press.
} 


\section{Introduction}

In a survey amongst alumni of Stellenbosch University, ${ }^{3}$ Erasmus (2006:25) summarized the results of his empirical research and gave verbatim reports on some of the answers to the open-ended questions in the focus group interviews. One respondent from the DRC wrote: "The most positive aspect in terms of knowledge and skills (question 3) was the help that I received from the Faculty to think theologically. The aspect that created the biggest challenge for me is the skill to manage and lead the congregation".

A minister from URCSA replied: "The other day I had a conversation with the chair of our circuit and he told me about a new course in administration that he attended. That is a very important aspect for me - I feel that I was thrown into the deep end in this regard. When I came into the ministry I was for the first time confronted with administrative issues and the way I tried to handle the issues was in many cases in conflict with the expectations of the congregation" (p.42, translation IN).

Another DRC alumnus replied: "My experience was that there was not enough emphasis on managerial skills. Most of my classmates are currently in congregations where they are responsible for the management and administration of the whole congregation, budget, projects et cetera - but they feel they do not have enough knowledge of the different aspects. In this regard I already had a conversation with Prof. X and sent him my views on how to incorporate a module into the Master of Divinity programme" (p.51, translation IN). ${ }^{4}$

These replies on the importance and necessity of training in leadership and administration are not lonely voices, for in the literature on the topic we find similar echoes. The Unisa practical theologian Marilyn Naidoo (2010:347) writes that "developing the next generation of quality leaders with good character and vision for the new millennium remains a major concern in church and society... while ministerial skills are important for church workers to possess, many have reached their ministerial posts with a great deal of intellectual knowledge and yet with little practical understanding of how to lead and administer the church population." According to scholars, this lack of continuity between what theology students are learning in the classroom and what they need to know once they enter the ministerial context is thus a source of concern (Banks 1999, Foster, Dahill, Golemon \& Tolentino 2006). ${ }^{5}$

\section{Terminological Clarification}

It is clear from the introduction that teaching leadership and administration is very important, but what it is all about and how to go about teaching these topics are not so clear. Frank (in Cahalan et al. 2008:67-73) underlines the numerous challenges when he writes about the problems with teaching leadership and administration, namely that nobody wants to take the courses, nobody knows what they are, most of the students have little or no clue what it is all about because they are not yet actually carrying the burdens of being a pastor

3 Naidoo (2012:10) refers to three main expressions of institutions that participate in the formation of students for ministry in South Africa. These are theological study at a public university, at a theological college or seminary and at institutions established primarily to equip lay persons for ministry. The focus in this study will be on the first expression, namely that of theological study at a public university.

Cf. also Burger \& Wepener (2004:8) on empirical research they did amongst ministers and members.

See in this regard also Duncan (2012:70): "There is a widespread dissatisfaction with the present training of the ministry, especially stress being laid on the assertion that it does not prepare candidates for the situations which they meet in real life in the parish". 
or carrying out the responsibilities of a full-time position in the church; there is no way to gain experience in these practices, nobody wants to teach the topic and the students might know what the lecturer is talking about but do not trust it. He concludes by stating (2008:72): "Because actually the biggest problem with theological reflection in a leadership and administration class in a school of theology is that in this dominant culture we are so unpracticed in language."

$\mathrm{He}$ is not the only person pointing out the problem of 'language practices' when it comes to reflection on leadership ${ }^{6}$ and administration from a theological perspective. ${ }^{7}$ In Michael Jinkins' chapter on Religious Leadership ${ }^{8}$ in the new Wiley-Blackwell Companion to Practical Theology (2012) he writes: "Though leadership has been an essential aspect of religious life from antiquity, its precise role and significance remain contested to this day in the academy and the church" (2012:308). One of the main reasons according to him lies in the very definition of the term, and the way these concepts and forms are utilized in many churches "bears the marks of secular ages, especially derived from business, social sciences, and political studies". 9

For the purpose of this article, I wish to concentrate on leadership for ordained ministry ${ }^{10}$ and I concur with Naidoo (2012:6) who is of the opinion that "Ordination sets people apart for particular leadership. It requires that the ordained explicitly and publically affirm that he or she is willing to let the church play a large role in the shaping of self." In

$6 \quad$ A definition of leadership used by many scholars was formulated by James Burns (1978:19) who defines leadership as "leaders inducing followers to act for certain goals that represent the values and the motivations - the wants and needs, the aspirations and expectations - of both leaders and followers". In this regard, he prefers to speak about "transforming leadership" that "looks for potential motives in followers, seeks to satisfy the higher needs, and engages the full person of the follower" resulting in "a relationship... of mutual stimulation and elevation that converts followers into leaders and may convert leaders into moral agents" (1978:4).

7 Burger \& Wepener (2004:6) speak in this regard of "certain obscurities" when they write: "For many ministers and church members there are certain obscurities regarding the essence of the task of a minister. Nationally and internationally there are numerous changes at different levels that are responsible for this state of affairs."

$8 \quad$ According to Jinkins (2012:310) "It remains an open question whether leadership as a field of study benefits from being understood as a discipline per se. At present it appears more likely that leadership should be viewed as a subject matter, an area of specialization, or a field of study within practical theology, though its disparate core concerns may make it more difficult to describe its disciplinary subject definitively than other specializations (such as homiletics, liturgics and pastoral counselling). However conceived, religious leadership tends to focus on concerns such as leadership proper, organizational behaviour, management, stewardship, finance, conflict, power, change, and professional ethics".

9 Burger (2004:539) is of the same opinion when he reflects on leadership within a congregational context: "Van die gemeentes waar dit skynbaar beter gaan, opereer baie sterk met gemeentemodelle en leierskapsmodelle wat ontleen is aan die sekulêre wêreld. Hoewel daar sekerlik nie fout is daarmee om uit die sekulêre wêreld en van die sosiale wetenskappe soos die organisasie- en bestuurswetenskap te leer nie, raak dit gevaarlik as hierdie modelle en selfs taal ons Bybelse taal en modelle begin oorneem. Ons identiteit as kerk het alles te doen met die taal en metafore waarmee ons leef en werk. As ons nie meer wat ons is en doen kan verbind aan Bybelse taal nie, gaan ons moeilik ons unieke identiteit as Christelike geloofsgemeenskappe handhaaf."

10 Ordained ministry is normally informed by confessional norms especially when there is a commitment to a particular faith tradition. But according to Jinkins (2012:309) it is also common among scholars in religious leadership "to reach across denominational and faith boundaries in their research, teaching and collegial conversations". In this regard he refers to the Anglican bishop and theologian Rowan Williams who uses the word "communicative theology" where religious leadership attempts "to persuade or commend, to witness to the gospel's capacity for being at home in more than one cultural environment, and to display enough confidence to believe that that this gospel can be rediscovered at the end of a long and exotic detour through strange idioms and structures of thought". 
this regard, vocation plays a central role normally consisting of a call from God, as well as a call from the church. Therefore, ordained ministry has a unique character ${ }^{11}$ where the identity centres around conforming oneself as a servant of the gospel (Van de Beek 2012:4). Naidoo (2012:6) summarizes: "The focus and end of authentic Christian leadership is not determined by the self-interest of the leader but by the self-giving nature of leadership characterised by humility and obedience."

To help find some clarity on the topic or 'language' of teaching leadership and administration, I wish to approach the discussion from a practical theological perspective ${ }^{12}$ by attending to the following aspects: The important influence of the changing scene on teaching leadership and administration, a historical probe to give an indication of what happened during the past century in different contexts, discuss some points of departure for reflecting on teaching leadership and administration, continue to describe four processes of formation that are operative in different pedagogies for teaching the subject to students and finally discuss some pointers for the way forward.

\section{A Changing Scene}

Much of the changing scene that impacts on ministerial formation and leadership on an international scale can be ascribed to globalisation that produced counter-reactions seen in the "growing trends towards either withdrawing Christian faith from public responsibility and dialogue altogether (privatisation), or to turn to denominational provincialism and ecclesial self-centredness (confessionalism), or to seek refuge in religious fundamentalism (simplification) within the Christian family, or in relation to other religions" (Werner 2009:71).

Another important factor that has changed the scene for ministerial formation and leadership is the shift from Christendom to a post-Christendom paradigm with the church finding herself on the periphery of society. According to Guder (1998:192) in the Christendom paradigm, the minister was the "shepherd to a static people and the provider of the focused and limited mission of caring for the church's members by ordering and dispensing the means of grace in a geographic locale. Leadership had a settled, pastoral identity now. The apostolic, as in missional, nature of leadership evaporated under these conditions." This shift from a Christendom to a post-Christendom paradigm influences the way leadership is exercised "because you need specific leadership qualities in a situation of change where the leaders are not only expected to preach and teach but also to be "missional leaders"' (Burger \& Wepener 2004:8).

The processes of change that influenced ministerial leadership in South Africa has even accelerated because of political and social shifts that have taken place since 1994. Smit (2008:92) speaks in this regard of a so-called 'collapse into modernity' that we experienced in our part of the world. Looking at deeper reasons for the changes, Burger and Wepener (2004:10-13) discuss topics such as an identity crisis, loss of traditional roles and tasks, the role of secularization, fragmentation of the office and the loss of wholeness, absence of focus where 'the centre cannot hold'.

11 Heitink (1999:317-324) distinguishes between the ecclesiastical character, the professional character and the personal character of the pastoral profession.

12 A practical theological perspective usually includes the following tasks: the descriptive-empirical, the interpretative, the normative and the pragmatic or strategic (Heitink 1999; Osmer 2008). 
Van de Beek (2012:2-4) identifies three major factors in the European context: 1) the Enlightenment with its criticism of irrational claims and power, 2) the shock of two world wars in the twentieth century, and 3) the main impact in the present situation of cultural, societal and religious diversification. He concludes:

Formerly church leaders were trained [in] how to attain their goals on the highways of culture and society, now they must be trained to go on roads without cultural and political directives, without any support of the environment, sometimes even through thorny bushes of all kinds of oppression. The present challenge for the church, for all denominations, is how they must train the new leaders, and that implies how to find students who want to be the new leaders, and that again implies to know what kind of leadership the church needs. And this is precisely the uncertainty we sketched above.

The rest of the article is an attempt to meet some of the challenges he poses with regard to the training of new leaders in this time of uncertainty.

\section{Historical Probe}

The Dutch practical theologian Gerben Heitink studied the development of ministry over the past five hundred years in the Netherlands and named it: Biografie van de dominee (2001). He worked with the hypothesis that one can understand the developments in the ministerial profession only in the light of developments in the church and that developments in the church can be understood only by understanding developments in society. He describes how the role of the minister changed during the various periods, from the initial years in Geneva, to the public role in the time of close church-state relations to the pedagogue of the 'volk', inner church administrator, pastoral leader, therapist to strategic leader.

In the USA, Van Gelder (2009:36-38) makes a similar analysis by discussing the different periods of the past two hundred years of developments in the mainline churches within the North American context. He points to the changing roles the pastor played from resident theologian, becoming the gentleman pastor, churchly pastor, pastoral director, therapeutic pastor to the modern day entrepreneurial leader and leader pastor in big independent community churches.

In South Africa we find similarities with Europe and the USA but also important differences because of our history of racial conflict and apartheid. One can see the historical development in the Dutch Reformed Church from 'sieketrooster' (person looking after the sick) to pastor, dominee (reverend), pastoral therapist, strategic manager, leader pastor to missional leader. Kritzinger (2012:34) points to the complex history of developments within the DRC family in South Africa: "The history of ministerial formation in the DRC family has been complex and ambigious" because of the mission policy of the DRC that aimed at creating autonomous and indigenous churches with a paternalistic attitude.

\section{Points of Departure in Developing a Framework}

For this part of the article, I am indebted to Frank (2006) who wrote a comprehensive research report on leadership and administration as an emerging field in practical theology. According to him, we have to pay attention to at least five questions in order to develop a framework. What follows is a summary of this section of his report (2006:123-135). 
- What are the critical issues in the field, and what makes them issues now?

He starts by making a bold statement on what he calls "the assumptions of a rhetoric of crisis":

Much of the literature in church leadership and administration is framed by the assumptions of a rhetoric of crisis. If an author can marshal the statistics to establish that the churches simply cannot go on like this, that there will be no more Presbyterians, Episcopalians, or even Christians in fifty years, that the race is won by churches that are swiftest to adopt new technology and programs and to jettison dated language and practices, he (usually he) can gain instant acclaim, sell more books, and collect more invitations to say more and more about the purported crisis. The rhetoric of crisis is a power play. It draws attention to the speaker, but more precisely, it lends credibility and force to the speaker's proposals for reform and action (2006:123).

He goes on to support his argument by referring to the metaphors that people use to discuss leadership. Very often it comes from the consumer culture where the product must be adapted to the wishes of the consumer. Comprehensive research needs to be undertaken into the presuppositions of this language because it happens repeatedly that language from the market place and independent churches is taken over while well-established theological and ecclesial vocabulary is jettisoned. A case in point is the use of a concept such as 'servant leadership' that many use without any ecclesiological grounding and forgetting about concepts such as diakonia and kubernesis.

Where one takes this route, it often happens that leadership is measured in terms of the success in making disciples (numbers) with the underlying assumption that we can measure leadership in terms of the performance of an individual. This is a sign of the loss of authority (cf. also Van de Beek) because we are no longer in the position to build convincing arguments from the language of the offices. The focus on performance equates leadership to productive and performing individuals and the result is a kind of double ecclesiological message. Although many emphasize the priesthood of all believers, the persons who actually count are the productive individuals in the top leadership positions. "This conclusion negates the most useful conceptions of leadership as a dynamic that circulates through a community empowering various persons in various circumstances to act for the well-being of the whole" (2006:126).

He ends this section by asking important questions: "What are the dynamics that stir the churches to adopt the rhetoric of leadership today? What is the relationship between leadership and office? How are forms of authority evolving in Christian communities? What gives legitimacy to the activities of certain Christians such as to merit the term leader?" (2006:126) and then summarizes: "Practical theologians can make a distinct, critical contribution as they address leadership and administration as a practice or set of ecclesial practices, embedded in traditions, sustained by and expressive of communities of faith, and circulating through churches and church organizations through the actions of varied persons in varied circumstances" (2006:127).

\section{- Through what practical theological method can the field of administration and leadership best be defined and shaped?}

Frank (2006:128) starts his discussion on methodology by pointing out the importance of what he calls the "correlation of scripture and contemporary organizational objectives". In short, it boils down to the ways in which authors and practitioners use Scripture in leadership studies and language. It often happens in very simplistic and fundamentalist 
ways where own frameworks are projected onto Scripture. According to him, a serious engagement from the side of practical theology includes the risk of entering a world with other presuppositions, many times standing in direct opposition to the values of contemporary culture and posing fundamental questions to faith communities.

In this regard, he points to 'reflective practice' as a useful approach: "This may still be the most constructive way to address both scripture and ecclesial traditions in one direction and contemporary situations and cultural changes in another. That is, leadership is best developed conceptually through a continuous conversation between practice and reflection, between situations and concepts, between depth understanding of current circumstances and sophisticated perception of situations that faith communities have faced in the past" (2006:130).

- How has administrative leadership been exercised in past generations of the churches, and what do situations in other times and places have to teach about contemporary practices?

In the historical probe we already looked at some pointers in this regard. Frank (2006:131) refers to the works of Thomas Oden: Pastoral Theology: Essentials of Ministry and the work by Richard Niebuhr and Daniel Williams: The Ministry in Historical Perspectives, that undertook this kind of analysis. According to him, a comparative analysis of different periods can be very useful. The struggle in the early church for authority and stability, the developments in medieval churches and the ministerial practices in post-Reformation churches are all resources filled with wisdom that can enrich our conversations and research.

\section{- How can the field be constructed more creatively from the diversity of voices and practices in the ecumenical church?}

The importance of this question posed by Frank (2006:131) cannot be overestimated. According to him, there is too much literature on the topic without any critical examination of the assumptions about culture, gender and the economic and social positions of the authors. Most books are still written by white males with an emphasis on effectiveness identified with masculinity. The enormous contribution of women at different levels of leadership and the power dynamics at work must be taken into account.

Further critical examination is also called for concerning different ethnic and cultural contexts that are at play. In many books on leadership, one recognizes the assumptions of white churches concerning aspects such as personal finances, suppressing of emotion in public worship and an ethic of time linked to productivity. If these ethnic norms are not examined critically, ecumenical conversations become very difficult. Leadership is always contextual: "Leadership and administration, like all ecclesial practices, are identifiable as distinct practices but never actualized outside of particular cultural contexts. Whatever people mean by leadership is deeply shaped by a culture of symbols, heritage, relationships, and arrangements of authority created over generations of experience by cultural groups" (2006:133).

In this regard we do have some experience of diversity at the Stellenbosch Faculty since URCSA moved its theological training to the Faculty of Theology at Stellenbosch 
University in $2000 .^{13}$ The importance of having students from different contexts in one class engaging in each other's contexts cannot be overestimated. The Belhar Confession with its emphasis on unity, reconciliation and justice plays an important role in the teaching curriculum. In the context of a local congregation, Osmer (2005) made an important contribution with a chapter in his book on The Teaching Ministry in Congregations under the title, "Leadership in the spirit of Belhar". He illustrates ways in which confessional language translates into leadership practices in a local congregation.

\section{- Are the fields of leadership and administration focused solely on churches and church institutions, or do they embrace practices of leadership for social transformation as well?}

"Finally, the practical theology of leadership and administration needs clarity about the focus of its subject matter. For the most part, the field is presently preoccupied with local church congregations. The performative paradigm reinforces this emphasis by making productivity of congregations primary" (Frank 2006:134). He goes on to argue why our research and conversations cannot be limited to congregational life. We do have to look at denominational bodies and other networks as well amidst the challenges of a consumer culture.

An important remark in this regard is the challenge to all who are interested in the topic of leadership and administration to consider social justice and transformation as ecclesial practice. The purpose is to look at justice and human dignity in societies and to research the role of churches as catalysts for the transformation of communities. It is interesting that he ends by referring to practical theology in South Africa as a case in point: "Practical theology in South Africa could serve as an exemplar in this regard. As a new South Africa emerges after generations of racial division and injustice, the churches must find their role as agents of reconciliation. They are positioned to take the lead in confessing sins of racial prejudice and hatred, and inspiring commitments to economic justice and social transformation" (2006:135).

\section{Different Pedagogies for Teaching Leadership and Administration}

The development of pedagogies is important not only for teaching leadership but it can take different routes. In what follows, I am using insights from the comprehensive study of Foster et al. (2006:67-186) titled: Educating Clergy: Teaching practices and pastoral imagination. In their work, they discuss four different strategies, which I have rearranged to correlate with a basic structure that I will explain further on. The words in brackets are my own qualifiers for the different pedagogies.

\section{Pedagogies of Formation (Character and Confidence)}

Students arrive at institutions of theological education already formed in different ways by faith communities and numerous other communities in which they grew up and participated. Formation of character is a lifelong process from cradle to grave. The distinguishing characteristic of formative pedagogies is that they strive to contribute to the formation of

13 In the meantime, agreements between Stellenbosch University and the Uniting Presbyterian Church in South African and the Anglican Church have also been signed for these institutes to allow their students to receive their training at the Faculty of Theology in Stellenbosch. 
knowledge, attitudes, skills and customs that are related to the development of a professional identity and with the accompanying practices, commitment and integrity contributing to character and confidence. The goal that a formative pedagogy strives for in the case of teaching leadership and administration, concerns involvement in the mystery of human existence (Foster et al. 2006:99-126).

Three approaches to pedagogies of formation can be distinguished, which include: The practice of the presence of God. This pedagogy is about making students aware of that which is holy and mysterious, which transcends the human consciousness through texts and reality itself. Sanctification as practice. This pedagogy concurs with the previous one, but also goes further "to live on every word and gesture, taste, touch, smell, sound, and sight of the liturgies they celebrate with people" (2006:104). The practice of religious leadership. This pedagogy is the practice of the attitudes and customs of the previous pedagogy, but specifically within certain roles and responsibilities related to the practices of a religious vocation. Students are guided to master certain skills that lead to the formation of patterns of leadership. This is related to the manner in which the interaction of institutional processes and the people participating in them is facilitated.

\section{Pedagogies of Information and Interpretation (Content and Curriculum)}

The theories of interpretation agree on the existence of four different realities in the process of interpretation. These include: a phenomenon which must be interpreted, the interpreter, the interaction of the interpreter with that which must be interpreted, and the interest of a community of interpretation. All these interpretation practices have one communal goal, which is to help students to think critically (Foster et al. 2006:70-99).

Different pedagogies of interpretation can be distinguished, including: Interpretation as a continuous dialogue in which various levels of dialogue can be discerned; Interpretation as the application of tradition and interpretation through the choice of the 'right method'. Here it is important to understand that the outcomes of the module determine the method. If there is consensus that it is about the development of critical thinking abilities, then it is important that the methodology should also serve the outcome. Should the goal of critical thinking be described briefly as 'understanding', the method should help students to develop the ability to make sense of texts, situations or contexts, and events. Thus, it is the capacity to analyse texts, situations and relations, and integrate them in a frame of understanding. Students must be guided to understand that they are part of an on-going dialogue with the source documents, traditions and contemporary practices of faith communities. ${ }^{14}$

\section{Pedagogies of Transformation or Performance (Courage and Commitment)}

Performative language provides the vocabulary to describe the public practice of the roles and responsibilities related to leadership and administration. The performance of the lecturer in class and the ultimate professional performance of students in the career world are not separate. Pedagogies of coaching which are to be found in actions such as the liturgy,

14 See in this regard a recent article by Smit (2012:81) on a "responsible theological hermeneutics" in which he gives a "brief overview of some of the popular descriptions (which could be called speech-acts in contemporary language) of the role of Scripture in the life of faith. Reflecting on such descriptions, a brief discussion focuses on the question of what the implications could be for so-called responsible hermeneutics in the life of the church." 
preaching and teaching are closely related to practices found in theatres, where performative language is supposed.

Thus, the term 'performance' is used widely to indicate a manner of thinking and doing, which is revealed in the actions of people's performances, in the rehearsing or putting into action of events. This performance takes place in specific times and circumstances, which are constantly shifting, and in the performance a specific embodiment of the action takes place (Foster et al. 2006:156-189). Another important aspect of this pedagogy is also to make students aware of the processes of social and systemic transformation of contexts in which these performances take place. Students become aware of their own and other cultural prejudices, and the importance of approaching social analyses from different perspectives.

\section{Pedagogies of Contextualization (Wisdom and Discernment - Phronesis)}

Pedagogies of contextualisation are those that emphasise the social situatedness of knowledge and practice in some way (Foster et al. 2006:127-155). In the case of the teaching of leadership and administration, it takes into account the students' situation as relative newcomers (rite of passage) in the academic discourse of practical theology.

In teaching students, the aim is therefore firstly to foster an awareness of their own context. The goal is to help them to reflect on the task of leadership contextually. A second pedagogy focuses on developing in students the ability to participate constructively in the meeting between their different contexts. Whether it is the context of the class situation, the meeting with a mentor or participation in activities in faith communities, it is all about developing the ability to interpret various contexts. The four pedagogies work together to address the different pedagogical needs of students.

\section{The Way Forward}

I would like to start this section on 'the way forward' by once again quoting Archbishop Emeritus Desmond Tutu in the foreword that he wrote to the new publication on Ministerial Formation in South African Churches (Naidoo 2012:x):

Our theological institutions must prepare students who will theologise acutely and proclaim prophetically, 'Thus saith the Lord'; they must carry out their ministerial functions competently; they must inspire with their preaching, and be compassionate in their ministrations to the People of God. But more than anything else they must be women and men of prayer... May it be so that they will be servant leaders emulating the One who came to serve and not to be served. That is the challenge that faces theological education in South Africa.

With the words of Desmond Tutu as a kind of an agenda, ${ }^{15}$ I think the following are some of the topics that we need to address in reflecting on teaching leadership and administration within the South African context on the way forward.

There are also other ways in which one could structure the conversation on the way forward. One example is the agenda that De Gruchy \& Ellis (2008) proposed, namely to concentrate on power, collaboration and a dialogical pedagogy. 


\section{Face the Contextual Challenges}

In Africa, we are facing numerous challenges of which HIV and AIDS, crime and corruption, poverty and exclusion are among the most obvious. The theological assumption that God is at work in the world and that the triune God calls and sends his people into the world, to live and work amongst all God's people has vast implications for the theological training of leadership.

Teaching leadership and administration must engage with this so-called missional praxis with a very specific orientation towards the world, in other words an outward orientation and one that focuses on the world rather than the church or scholarship. According to De Gruchy (2010:42) "This claim is rooted in the important missiological recognition... that the church find the reason for its existence in its willingness to respond to what God is doing in the world."

In a document of the World Council of Churches, The Church for Others: Two Reports on the Missionary Structure of the Congregation (Geneva: WCC, 1969:14), the authors seek to define the purpose of the Missio Dei by referring to the biblical term shalom. "This word is used to indicate all aspects of human life in its full and God-given maturity: righteousness, truth, fellowship, peace, etc." Some of the guiding metaphors they use together with shalom are the kingdom and life.

This insight should have a profound impact upon teaching leadership and administration both in terms of the content and the process of such teaching. When teaching leadership "is removed from its missiological orientation it loses touch with the world, and it turns inwards" (2010:43). Skillful contextual hermeneutics are therefore necessary to read the context in order to discern and prioritize leadership activities (Vanhoozer 2002, 2005).

\section{Be Compassionate... to the People of God}

Without compassion for all the children of God living in the world, the way forward for leadership can become a cul-de-sac. The shepherd metaphor draws on deep biblical and traditional roots where the shepherd or pastor is mindful that the church, as the missiones ecclesia, is best understood as an organ or a body directed toward life in all its fullness. The shepherding metaphor is therefore in line with the understanding of the church as a 'living organism' or an 'open system'.

In this regard Dittes (1979:1) understands the cost of leadership when approached as shepherding:

To be a minister is to know the most searing grief and abandonment, daily and profoundly. To be a minister is to take as partners in solemn covenant those who are sure to renege. To be a minister is to commit, unavoidably, energy and passion, self and soul, to a people, to a vision of who they are born to be, to the readiness to share and live into that vision. To be a minister is to make that all-out, prodigal commitment to a people who cannot possibly sustain it. That is the nature of ministry, as it is of the God thus served.

Facing contextual problems and being compassionate to the people of God form part of the so-called descriptive-empirical task of practical theology by asking the question: What is going on? This task focuses on the actual state of some form of Christian praxis, in this case leadership and administration, in a particular context. Therefore it seeks to investigate empirically and to describe as fully and accurately as possible a particular field of experience, and it requires a 'spirituality of priestly presence' (Osmer 2008:4). 
Theologise Acutely

To 'theologise acutely' Christian theologians turn to Scripture and tradition as their normative sources. To theologize in this situation is to ask critical questions that link our 'faith seeking understanding' with the concepts of leadership and administration. Looking for clues on leadership in the Bible provides a variety of perspectives. Apart from the narratives on the lives of various leaders in the Old Testament, from the patriarchs to the judges and kings, Brueggemann (1978:44-61) argues that the prophetic literature effectively relativizes the totalizing claims of 'the royal consciousness' of ancient Israel.

In the New Testament accounts of leadership, we find what Jinkins (2012:310) calls the "counterintuitive nature of Jesus' teachings" in the synoptic Gospels. "Jesus 'assumes' leadership but does so in ways that radically challenge the conventional meaning of the term in his culture. His understanding, for example, refuses to 'lord it over' others." The well-known Phil 2:1-10 is the Pauline contribution to the 'servant character' of the way in which Jesus exercised this counterintuitive leadership role.

According to the important document of the World Council of Churches Baptism, Eucharist and Ministry (1982:24) it is clear that the New Testament testifies to a variety of roles and offices, but it does not reflect "a single pattern of ministry which might serve as blueprint or continuing norm for all future ministry in the Church". The most common reference we find in the New Testament to the role of leadership is that of bishop or overseer (episcopos), while we also find other offices such as elder (presbuteros) and deacon (diaconos) from the same period. Bartlett (1993:132-133) points out the importance of the image of the shepherd, and relates leadership to concepts such as stewardship and guardianship. "The bishop, presbyter, or elder charged with leadership is the shepherd and steward of the community, inheriting and transmitting faithfully the apostolic message, ensuring the safety of God's flock..." (Jinkins 2012:311).

A very important aspect of theologizing acutely is taking cognizance of the close link between our God images and our understanding of leadership roles. Zscheile (2007) in his article on Trinity, Leadership and Power, reflects on the rediscovery of the doctrine of the Trinity as one of the major themes of Western theology in recent decades, and he goes on to discuss the leadership implications of this Trinitarian resurgence. "In particular, the question of power and authority in religious leadership bears reconsideration in light of a trinitarian imagination. Solitary, monarchical, hierarchical, and authoritarian patterns of leadership have come under increasingly critical scrutiny in the church and academy - to say nothing of the wider culture" (2007:43).

\section{Proclaim Prophetically}

Many people all around the world know the prophetic quality of the person and message of Desmond Tutu. Unfortunately, in the recent past we have not seen many other prophets within the South African context. However, that does not take away the necessity of prophetic activity as part of our missional engagement. ${ }^{16}$

David Bosch (1993:389-393) was a prophetic voice in his own right and he helped us to realize that the triune God is also a missionary God, a sending God reminding us of the huge implications this vision has for theology:

16 See a recent publication by Nora Tubbs-Tisdale (2010) in this regard: Prophetic Preaching: A Pastoral Approach (2010, Westminster: John Knox Press), in which she refers inter alia to Tutu's contribution to prophetic preaching. 
Just as the church ceases to be church if it is not missionary, theology ceases to be theology if it loses its missionary character. The crucial question, then, is not simply or only or largely what church is or what mission is: it is also what theology is and is about. We are in need of a missiological agenda for theology rather than just a theological agenda for mission, for theology rightly understood, has no reason to exist other than crucially to accompany the missio Dei.

In this regard we are seeing the emergence of a different understanding of leadership and administration, namely that of the missional leader engaging changing contexts. The missional leader "recognizes the contextual character of all theology and cultivates and imagination for relating to the "other"' (Small 2009:44). If you work from this perspective, teaching leadership calls for keeping in mind the world as the larger horizon of God's work. $^{17}$

One way to understand the prophetic task of leadership, is to connect it to what De Gruchy (2010:42-46) calls the 'missional praxis' of theological education. Theological education and the teaching of leadership and administration require this missional praxis in at least four important ways: 1) An orientation towards the world, 2) furthering the telos of life, 3) learning from engaged praxis, and 4) being intentionally interdisciplinary. ${ }^{18}$

The first two have already been touched upon briefly. Concerning learning from engaged praxis we have found in South Africa that "the missional engagement of Christians alongside people of other faiths, or of no faith, in the struggle against HIV and AIDS (for example) raises new questions about God, suffering, inter-faith dialogue, stigma and inclusion, the boundaries of the church, health and sickness, and church-state relationships" (De Gruchy 2010:45). This brings us necessarily to interdisciplinarity. Teaching leadership and administration needs to be interdisciplinary in nature and therefore necessitates helping students to understand the world in all its complexities, as they need to understand all the other subjects in the curriculum.

The theological and prophetic aspects concerning the teaching of leadership relates to the normative task of practical theology, where we ask the question, "what forms ought Christian praxis to take in this particular social context?" (Osmer 2005:xiv). This task focuses on the construction of theological and ethical norms with which to assess, guide and reform some dimensions of contemporary Christian praxis and looks to the normative sources (biblical studies, systematics, ethics, history etc.) of the Christian faith. According to Osmer (2008:4) this task requires a spirituality of 'prophetic obedience'.

\section{Carry out Ministerial Functions Competently and Imaginatively}

Osmer (2008:176) distinguishes three forms of leadership that could be linked to competent and imaginative ministerial functions. The first he describes as task-leadership. This is the ability to perform certain roles successfully in organisations. In respect of churches and congregations, this is the role that leaders play, for example, to lead a worship service, proclaim the Word, instruct members, establish a small group, practise pastoral care, chair

17 A recent publication by Doornenbal (2012) Crossroads: An Exploration of the Emerging-Missional Conversation with a Special Focus on Missional Leadership and Its Challenges for Theological Education, explores leadership within the missional church as well as the emerging church movements and calls it the "emerging missional conversation," showing in what ways these movements challenge theological education. 
meetings and visit congregants in hospital. A large part of theological training is about preparing students to fulfil these different tasks with the necessary knowledge, attitudes and skills within a variety of faith communities.

The second form of leadership is transactional leadership, which consists of reciprocity, i.e. an attitude of where I can do something for another to which he/she can reciprocate. This is a 'trans-act' or reciprocal act of giving and receiving. According to Osmer (2008:176), this takes place in two basic ways in the leadership of organisations: "(1) meeting the needs of those involved in an organization in return for their contribution to the organization, and (2) making political trade-offs to deal with competing agendas of different coalitions in an organization so that it can best accomplish its purpose."

The third form of leadership is transformational leadership, which is about 'deep change' (Robert Quinn's term), and is related to leading an organization by a process in which identity, mission and culture are fundamentally transformed. Within a congregational context, this is about the transformation of worship, fellowship, reaching out and hospitality to new members who are different. This is about developing a vision of what the congregation can become and the mobilization of followers who are willing to subscribe to this vision. Osmer (2008:179) is of the opinion that these three forms of leadership in faith communities are all necessary, but that today, especially in the mainstream Protestant churches, the greatest need exists for transformational leadership.

\section{Serve and not to be Served}

In the New Testament, we see how Christian leadership is the continuation of the ministry of Christ and of God where the 'service motive' is of central importance. Right through the New Testament we find that the authors use the word diakonia for this kind of service. In Mark 10:43-44 we hear from Jesus “... but whoever would be great among you must be your servant, and whoever would be first among you must be slave of all”. In Phil. 2:1-11 Paul reflects in his well-known hymn on the way Jesus emptied Himself to become a slave on our behalf through the humiliation on the cross. ${ }^{19}$

It is in this regard that Van de Beek (2012:4) writes "Future church servants must be trained to build up the body of Christ in its self-understanding as community which participates in his eternal life ... they serve the people by making them aware of the freedom of a Christian in the freedom of Christ. People who are really free are able to serve other people ... they serve in compassion and care... Future ministers must be trained to lead the congregation to Christ, living in true freedom and therefore being able to be everyone's servant."

19 See in this regard the following comments on the concept of Kenosis: "Jesus wys deur sy menswording hoe God bedoel het menslikheid en medemenslikheid moet lyk. Inkarnasie en navolging van Christus vertel ook iets van die kwesbaarheid van die kerk. Dit bring die gedagte van kenosis in die gesprek in. Kenosis is die teenoorgestelde as selfhandhawing en selfvervulling. Dit is ' $n$ gesindheid om ter wille van die ander of in die plek van die ander te gaan staan en leef - soos wat Christus mens geword, slaaf geword en in ons plek gesterf het. Kenosis - om jouself leeg te maak - is 'n ingesteldheid of 'n houding of selfs 'n soeke. Dit kan ook beskryf word as om jou doelbewus kwesbaar te stel. As die kerk dus gekonfronteer word in Afrika met HIV/Vigs is die vraag wat die kenosis-gesindheid sou vra - hoe die kerk ook HIV-positief kan raak en nie hoe kan ons in die eerste plek die vraagstuk oplos nie. Kenosis is in die hart van die gestuurde teologie. Selfontlediging ter wille van die skep van 'n gemeenskap met diegene na wie die Here ons stuur, is die pad waarop die gemeente loop in navolging van Christus sodat die potensiaal kan ontstaan dat die nuwe gemeenskap kan gebeur" (Agenda Algemene Sinode 2011:136). 
The ministerial functions and service motive concerning the teaching of leadership relate to the pragmatic task of practical theology where we ask the question: "how might this area of praxis be shaped to more fully embody the normative commitments of the Christian tradition in a particular context of experience?" (Osmer 2008:4). The pragmatic task allows one to focus on the development of action-guiding models and rules of art from a strategic point of view and requires a spirituality of 'servant leadership'.

\section{Women and Men of Prayer}

In his section on spirituality Kritzinger (2012:41) states: "In order to overcome the legacy of exclusion and division from the past, we need a spirituality that is rooted in grace, inclusively African, reconciling, creation-affirming, anti-racist and ex-centric (or missional)." He goes on to discuss each of these factors in more detail, but his words concerning 'inclusively African' are maybe the biggest challenge to teaching leadership and administration within the South African context:

What we need as an underlying ethos for everything we do in ministerial formation is a spirituality of inclusion, reaching out to people who are different, thinking them into our lives as part of our world; a way of life that does not say (or even think); 'the coloureds have a gangsterism problem', 'the Afrikaners have a racism problem', or 'the poor black communities have a xenophobic problem', etc. Instead, it will say: 'we have a gangsterism problem in some of our townships', 'we have a racism problem in some of our communities', etc.

He summarizes his argument by pointing to the fact that the kind of spirituality we need for a new phase in the praxis of ministerial formation is a 'missional spirituality'. This kind of spirituality consists of "an awareness that the Spirit of life, working and living within us, sends us into the community to live good news to and with all. We will only overcome the power of our prejudices, suspicions, grudges and vested interests if we commit ourselves together to God's mission in society".

\section{Conclusion}

Effective integration or balancing of the mentioned aspects within the curriculum for teaching, leadership and administration in theological institutions is not easily achieved (Naidoo 2012:4). According to Duncan (2012:70) there will always be forms of dissatisfaction - which is not necessarily a bad thing because it keeps the matter on the agenda and under constant review. "It also has to be considered whether or not it is ever possible to have an ideal state in formation as we are all continuously in the process of formation as Christians, that are journeying and not yet arriving at our destination."

In an attempt to synthesise the different aspects discussed in the previous section into some kind of a systematic model for teaching leadership and administration, the so-called munus triplex is still very helpful. ${ }^{20}$ One way to approach such a synthesis, in making use of

\footnotetext{
20 Burger (2004:545) relates it in the following way to the office of the minister: "As daar nou samevattend gevra word wat ons uit die drie ampte kan leer oor die inhoud van predikantswerk in ons tyd, sou die volgende riglyne gegee kon word. Die voorstel is dat ons met 'n breë indeling werk waarvolgens die priesterlike werk gefokus word op nabyheid aan mense en hul lewens, profetiese werk gefokus word op nabyheid aan God, sy woord en die beloftes van sy evangelie en die koninklike werk gefokus word op die organisasie en bestuur van die "huishouding van God" ter wille van die beliggaming van die evangelie in die gesamentlike lewe van die gemeente."
} 
the munus triplex, is to look at what Wainwright (1997) sees as the problems or challenges lying behind the activities of the three offices (priest, prophet and king) to which Christ as Saviour responds. According to him, it is the problem of human estrangement (priest), the problem of knowledge and meaning (prophet) and the problem of power and authority (king).

Concerning facing the contextual challenges and compassion towards the people of God, one finds that these notions link to a spirituality of priestly listening, relating to pedagogies of formation and contextualization and respond to the many different situations and episodes of estrangement in academy, church and society, focusing on closeness to people.

Concerning theologising acutely and proclaiming prophetically, one finds that these notions link to a spirituality of prophetic discernment, relate to pedagogies of information and interpretation and respond to the problem or challenge of a lack of knowledge and the search for meaning in academy, church and society, focusing on closeness to God.

Concerning carrying out ministerial functions competently and imaginatively and serving other people, one finds that these notions link to a spirituality of servant leadership, relate to pedagogies of transformation and performance, and respond to the problem or challenge of power and authority in academy, church and society, focusing on organizing and managing the 'household of God'.

"Women and men of prayer" is in a certain sense then the point of integration, the place where we live Coram Deo and where we hear God's voice calling us (vocation) to be "Church servants for the future" (Van de Beek) living with phronesis and a keen awareness that the Spirit of life, working and living within us, sends us into the community to live good news to and with all.

\section{BIBLIOGRAPHY}

Banks, RJ 1999. Re-envisioning theological education: Exploring a missional alternative to current models. Grand Rapids: Eerdmans.

Bartlett, DL 1993. Ministry in the New Testament. Minneapolis: Fortress Press.

Bosch, DJ 1991. Transforming mission: Paradigm shifts in theology of mission. Maryknoll, NY: Orbis Books.

Brueggeman, W 1978. The Prophetic Imagination. Minneapolis: Fortress Press.

Burger, C 2004, "Die predikantsamp. Deel 4: Predikantwees in die Gereformeerde tradisie in die 21 ste eeu - nuwe uitdagings en nuwe tendense", Dutch Reformed Theological Journal = Nederduitse Gereformeerde Teologiese Tydskrif, vol. 45 , no. $3 \& 4: 529-537$.

Burger, C \& Wepener, C 2004. Die predikantsamp. Deel 1.Onduidelikheid oor die kerninhoud van die predikantsamp. Dutch Reformed Theological Journal = Nederduitse Gereformeerde Teologiese Tydskrif, vol. 45, no. 1 \& 2:5-14.

Cahalan, K, Hess, CL \& Miller-McLemore, B 2008, “Teaching Practical Theology: Introducing Six Perspectives.” IJPT, vol. 12:35-87.

De Gruchy, S 2010. Theological Education and Missional Practice: A Vital Dialogue, in:

Werner, D et al. Handbook of Theological Education in World Christianity: 
Theological Perspectives, Regional Surveys, Ecumenical Trends. Oxford: Regnum:42-50.

De Gruchy, S \& Ellis, W 2008. Christian Leadership in 'Another Country': Contributing to an Ethical Development Agenda in South Africa Today. In S De Gruchy, From Our Side: Emerging Perspectives on Development and Ethics (9-20). Amsterdam: Rozenburg Publishers.

Dittes, JE 1979. When the People Say No: Conflict and the Call to Ministry. New York: Harper \& Row.

Doornenbal, R 2012. Crossroads: An Exploration of the Emerging-Missional Conversation with a Special Focus on Missional Leadership and its Challenges for Theological Education. Delft: Eburon.

Duncan, G 2012. Ministerial formation in the South African Presbyterian tradition, in Naidoo, M (ed.) Between the real and the ideal: Ministerial formation in South African churches. Pretoria: Unisa Press:63-74.

Erasmus, J 2006. Verslag: Persepsie oor teologiese opleiding onder oud-studente (2000-2005). Samesteller: JC Erasmus: Eenheid vir Godsdiens- en Ontwikkelingsnavorsing (EGON), Stellenbosch Universiteit. Opdrag van Dekaan Fakulteit Teologie, Stellenbosch Universiteit . Unpublished report.

Foster, CR, Dahill, LE, Goleman, LA, Tolentino, BW 2006. Educating Clergy: Teaching Practices and Pastoral Imagination. San Francisco: Jossey-Bass.

Frank, TE 2006. Leadership and Administration: An Emerging Field in Practical Theology. Research Report. International Journal of Practical Theology. Vol 10:113-152.

Guder, DL, \& Barrett, L 1998. Missional church: A vision for the sending of the church in North America. Grand Rapids: Eerdmans.

Jinkins, M 2012. Religious leadership, in The Wiley Blackwell Companion to Practical Theology. Aldershot: Ashgate. 307-317.

Heitink, G 2001, Biografie van de dominee. Baarn: Ten Have.

Heitink, G 1999. Practical theology: History, theory, action domains: Manual for practical theology. Grand Rapids: Eerdmans Publishing.

Kritzinger, JNJ 2012. "Ministerial formation in the Uniting Reformed Church in Southern Africa: In search of inclusion and authenticity", in: Between the Real and the Ideal, Naidoo, M (ed.) Pretoria: Unisa Press:33-47.

Naidoo, M 2010, "Ministerial training: The need for pedagogies of formation and of contextualisation in theological education." Missionalia, vol. 38, no. 3:347-368.

Naidoo, M (ed.) 2012. Between the Real and the Ideal: Ministerial formation in the South African Churches. Pretoria: Unisa Press.

Osmer, RR 2005. The teaching ministry of congregations.Louisville, Kentucky: Westminster John Knox Press.

Osmer, R 2008. Practical Theology: An Introduction. Grand Rapids, Michigan: Eerdmans.

Small, KJA 2009. Theology for Schools of Theology: Re-engaging the Question "What is Theological about a Theological School?", in: Van Gelder et al. The Missional Church \& Leadership Formation: Helping Congregations Develop Leadership Capacity. Grand Rapids, Michigan: William B Eerdmans Publishing Company:4571. 
Smit, DJ 2008. "Mainline Protestantism in South Africa - and modernity? Tentative reflections for discussion", Dutch Reformed Theological Journal, vol. 49, no. $1 \& 2: 92-105$.

Tubbs-Tisdale N 2010. Prophetic Preaching: A Pastoral Approach.Westminster: John Knox Press.

Van de Beek, A 2012. Church servants for the future. Unpublished paper as background for the MTB-conference.

Van Gelder, C (ed.). 2009. The Missional Church \& Leadership Formation: Helping Congregations Develop Leadership Capacity. Grand Rapids, Michigan:

William B Eerdmans Publishing Company.

Vanhoozer, KJ 2002. First Theology: God, Scripture \& Hermeneutics. Intervarsity Press.

Vanhoozer, KJ 2005. The drama of doctrine: a canonical-linguistic approach to Christian theology. Louisville, KY: Westminster John Knox Press.

Wainwright, G 1997. For our salvation: two approaches to the work of Christ. Wm B Eerdmans Publishing.

Werner, D 2009. Magna Carta on ecumenical formation in theological education in the $21^{\text {st }}$ century: 10 key convictions. International Review of Mission 98 no. 1:161-170.

Werner, D, Esterline, D \& Kang, N (eds.) 2010. The Handbook of Theological Education in World Christianity. Oxford, UK: Regnum Books International.

World Council of Churches 1969. The Church for Others: Two Reports on the Missionary Structure of the Congregation. Geneva.

World Council of Churches 1982. Baptism, Eucharist and Ministry. Geneva.

Zscheile, DJ 2007. “The Trinity, leadership, and power". Journal of Religious Leadership, vol. 6, no. 2:43-63. 